\title{
Assessment of vulnerability to storm induced flood hazard along diverse coastline settings
}

\author{
Nikolay Valchev ${ }^{1, a}$, Nataliya Andreeva ${ }^{1}$, Petya Eftimova ${ }^{1}$, Bogdan Prodanov ${ }^{1}$ and lliyan Kotsev ${ }^{1}$ \\ ${ }^{1}$ Institute of Oceanology, Coastal Zone Dynamics Department, 40 Parvi May Blvd., Varna 9003, Bulgaria
}

\begin{abstract}
European coasts suffer notably from hazards caused by low-probability and high-impact hydrometeorological events. The aim of the study is to assess in probabilistic terms the magnitude of storm-induced flooding hazard along Varna regional coast (Bulgaria, western Black Sea) and to identify susceptible coastal sectors (hotspots). The study is performed employing the Coastal Risk Assessment Framework (CRAF) developed within EU FP7 RISC-KIT project. It constitutes a screening process that allows estimation of relevant hazard intensities, extents and potential receptors' exposure vulnerability within predefined sectors. Total water level was the chief property considered for calculation of coastal flooding hazard. It was estimated using Holman model (for sandy beaches) and EurOtop formulation (for artificial or rocky slopes). Resulting values were subjected to Extreme Value Analysis to establish that the best fitting distribution corresponds to Generalized Extreme Value distribution. Furthermore, hazard extents were modelled by means of bathtubbing or overwash estimation in order to form the flooding hazard indicator. Land use, social vulnerability, transport systems, utilities and business settings were considered as exposure indicators. Finally, potential risk was assessed by coastal indices following an index-based methodology, which combines hazard and exposure indicators into a single index, thereby providing base for comparison of coastal sectors' vulnerability. The study found that the concentration of hotspots is highest in Varna Bay.
\end{abstract}

\section{Introduction}

Storms and related disasters are one of the most important phenomena producing coastal hazards and endangering human life and occupation. Recent and historic high-impact events (e.g. Xynthia [1], Ligurian Flash Floods [2] and 1953 North Sea storm surges [3]) have proved the damage that could be caused by marine hazards, which European coastal areas are exposed to. In western Black Sea, particularly large damage was caused by storms that occurred in the late 1970s and the early 1980s, although increased storm activity was also observed in the early 1990s [4-6]. Even if the past decade has seen a return to relatively calmer storm conditions, reducing vulnerability to storm impacts is not likely to be expected, especially considering severe storms during 2010-2012 [7-9].

Recent climatic studies have revealed that coastal risk is likely to increase in the future due to increase of frequency and intensity of coastal hazards, such as surgedriven floods, erosion and flash floods [10]. On the other hand, due to population growth in coastal areas - already $40.8 \%$ of the EU population lives in coastal regions [11] - risk is also likely to increase since the consequences will possibly increase as well.

For these reasons, storm-induced flooding has recently become a topic of increased scientific and political interest. Thus, the EU Floods Directive [12] identifies marine inundations and resulting negative geoecological and socio-economic consequences as a specific category representing major environmental threat for European coasts. Therefore, it requires Member States to assess if water sources and coastlines are subject to flood risk, to map the flood extent, assets and population at risk in vulnerable areas, and to take adequate and coordinated measures to reduce the flood risk.

Hence, the aim of the present study is to assess in probabilistic terms the magnitude of storm-induced flooding hazard along Varna regional coast and to identify coastal hotspots in support to coastal managers, decision- and policy-makers. Results can be used for further high resolution risk modelling of the most vulnerable areas and for design of disaster risk reduction strategies aimed at increased coastal resilience to low-frequency, high-impact hydro-meteorological events.

The study is performed employing the Coastal Risk Assessment Framework (CRAF) developed within EU FP7 project RISC-KIT (Resilience-Increasing Strategies for Coasts - toolKIT) [13]. Briefly, this framework constitutes a screening process that allows delimitation of susceptible alongshore sectors (hotspots) by assessing relevant hazard intensities, hazard extents and potential receptors' exposure vulnerability within them. This assumes sufficiently accurate reproduction of existing (or

\footnotetext{
${ }^{\mathrm{a}}$ Corresponding author: valchev@io-bas.bg
} 
projected) spatial variability of both coastal morphology and hydro-meteorological forcing in terms of extreme storm events. The latter provides different combinations of boundary conditions that result in certain response to a hazard. Eventually, the variety of estimated responses (representing entire range of natural variability of coastal hazard for all tested conditions) gives possibility to perform a probabilistic analysis on the obtained coastal impact dataset $[14,15]$. The main outcome is the probability distribution function of a given hazard that allows hazard parameters of interest to be directly evaluated. Receptors taken into consideration in the framework are land use, population, transport, utilities and economic activities.

Finally, the approach in use results in assessment of potential risk through calculation of coastal indices following an existing index-based methodology. It combines several hazard and exposure indicators into a single index, thereby allowing a rapid comparison of coastal sectors vulnerability [16-18].

Index-based approach was applied extensively worldwide [e.g. 19-22]. Similar studies were performed for Varna regional coastline as well [23, 24].

\section{Study site}

The study site comprises the coast of Varna region located on the western Black Sea. Regional coastline, with an approximate length of about $70 \mathrm{~km}$, stretches from cape Ekrene to the north to cape St. Atanas to the south, including Varna Bay (Figure 1). Northward, between cape Ekrene and cape St. George the coast is marked by cliffs and beach bodies of different dimensions, and is occupied by several seaside resorts with international importance: Golden sands, Holiday Club Riviera, Kabakum, Sunny day Co., St. Constantine $\&$ St. Helena, and Euxinograd. The northern arm of Varna Bay is entirely protected by coastal defense structures, which resulted in formation of several beaches that nowadays alternate with rocky revetments. In the most inner curve of Varna bay lays a sandy spit - lowlying area cut by two artificial navigable canals connecting Varna bay to Varna Lake, which itself is linked to Beloslav Lake. This area holds the largest in Bulgaria transport and port agglomeration VarnaBeloslav-Devnya industrial complex. To the south of cape Galata the coast is presented by high cliffs reaching up to $125 \mathrm{~m}$. Further on, between cape Paletsa and cape Cherni nos, the longest beach $(13 \mathrm{~km})$ along the Bulgarian Black Sea coast - Kamchiya-Shkorpilovtsi beach - is located. It is the only beach within the study area with dune presence. In the most southern end of the site, between cape Cherni nos and cape St. Atanas, the coast consists of narrow beaches backed by high cliffs and limited by rocky capes.

Study site coast is divided between five coastal municipalities: Aksakovo, Varna, Avren, Dolni Chiflik and Byala (Figure 1), of which only Varna and partly Avren comprise economic activity of international importance (e.g. port and seaside resorts), while others have regional, mostly touristic, value.

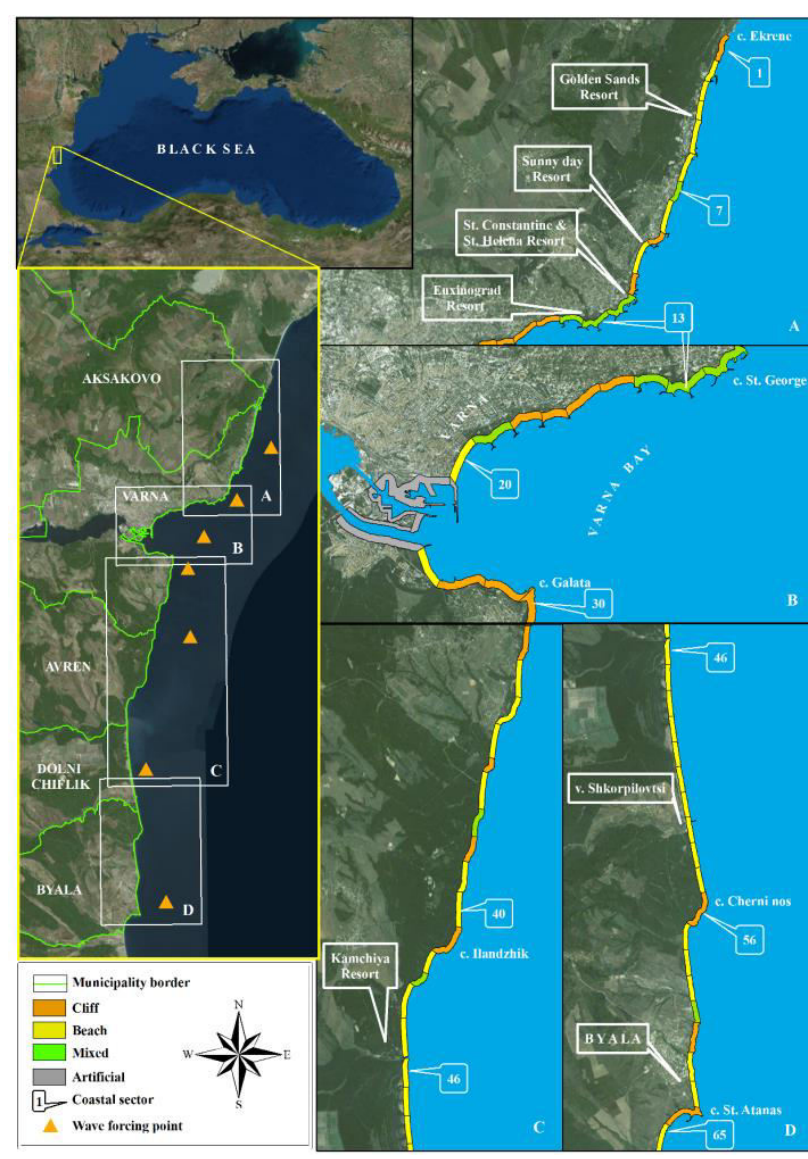

Figure 1. Schematic map of the study site indicating coast types within predefined sectors and location of grid points for wave forcing time series

To the south of cape Galata the coastal area is weakly urbanized, mainly represented by villa zones, camping and bungalow sites, and holiday homes with seasonal touristic activity. Regional boundary of the study site with respect to flooding hazard was set at the municipal level and is expected to account for presence of critical infrastructure and possible ripple effects.

\section{Data and methods}

Generally, coastal flooding is caused by a combination of high water levels (storm surges plus high tides) and wave action (wave induced run-up). Since the Black Sea is considered a basin of weak tides, only storm surge and wave run-up were taken to form the total water level (TWL). Subsequently, the TWL was converted into associated hazard (flooding potential) by empirical hazard models. Furthermore, maximum potential land surface to be flooded was modelled by means of bathtubbing or overwash estimation.

\subsection{Morphological setting}

A high resolution Digital Elevation Model (DEM) is a prerequisite for reliable assessment of hazard intensities and resulting extents in the hinterland. Hence, such DEM, having mean sea level as reference datum, was created for the study area by means of the following components. 
The first one was ortophotogrametric digital surface model of $10 \mathrm{~cm}$ horizontal and vertical resolution available for two coastal areas: a strip located northward of Varna comprising several international seaside resorts (sectors 2-7) and Varna city coast (sectors 17-29). The topography of areas outside those high resolution domains was obtained from 1:5 000 topographic maps by digitizing contour lines up to $30 \mathrm{~m}$ a.m.s.l. [25]. These sets were complemented by field measurements at several beaches situated within the study site and performed in 2010-2011. Shallow water bathymetry was generated using data from single-beam echo-sounder surveys. Thus, the resultant DEM has $1 \mathrm{~m}$ horizontal and $10 \mathrm{~cm}$ vertical resolution.

For the study purposes, Varna regional coast was divided into 65 coastal sectors of average length $\sim 1.1 \mathrm{~km}$ according to the predominant morphological setting: 33 of sectors are mainly sandy beaches ( 8 of them are marked with dune presence), 14 are cliffs of various height, and 11 are artificial (man modified), while 7 sectors are of mixed type - cliffs with adjacent small beaches. In Figure 1, coast types are shown as coloured strips corresponding to each sector, as strip width is selected purely for visual representation purposes.

Sectors were characterized at least by one representative average profile (average scenario) and one sensitive profile (worst scenario) as the total number of profiles was 159. Generally, they were selected depending on their slope. The worst scenario was defined by profiles with steeper slopes inducing larger run-up for the same forcing conditions, which is valid for continuously rising slopes, in particular. In case of lowlaying coastal topography (optionally with dune presence) scenarios were determined on the basis of overwash extent magnitudes. For average scenario, the range of profile slopes is $0.014 \div 0.391$, while for worst one $-0.037 \div 0.562$.

\subsection{Extreme event definition}

The study follows response approach [26] making use of long-term water level and wave data to estimate flooding hazard parameters - wave run-up, total water level and overwash. This implies definition and selection of extreme events and generation of storm surge and wave time series for each coastal sector.

Extreme events were determined using wave hindcast data obtained by means of nested WAM-SWAN wave model train with maximum resolution of $400 \mathrm{~m}$ and covering 57-year period (1949-2006) [23, 27]. The wave models were forced with wind data originated from regional atmospheric model REMO [28]. Selected grid points for extraction of wave climate time series are shown in Figure 1. Storm surge data covering the same time-span consist of tide gauge daily measurements at bay conditions (Varna Bay) and at open shore.

Peak over threshold (POT) analysis was used to identify the individual coastal storms using threshold of $2 \mathrm{~m}$ for significant wave height, which should be exceeded for a time-span longer than 18 hours. The threshold for significant wave height was selected since it represents the 99 percentile, while duration was set on the basis of measured morphological impact of short-lived storms of equal intensity at two beaches within the study area. The impact was considered important in terms of thresholds established in [29]. Thus, 144 storm events were selected, each represented by surge level, significant wave height, peak wave period, mean wave direction and storm duration.

\subsection{Hazard intensity}

Once the forcing along the coast has been defined, resultant hazard intensities were assessed using empirical models applicable to each type of coast presented at the study site. Herein, the TWL, represented as a superposition of storm surge level and wave-induced runup, was the chief property considered for calculation of coastal flooding hazard. In case of sheltered areas such as ports and canals only surge level component was taken into account. Three empirical models were considered for calculation of wave run-up, namely Stockdon model [30], Holman model [31] and model of Nielsen \& Hanslow $(\mathrm{N} \& \mathrm{H})$ [32]. Wave run-up estimates obtained as a result of their application were compared with measurements of maximum run-up position performed at four sandy beaches within the study site domain. Validation datasets comprised six storm events representing wide range of storm conditions.

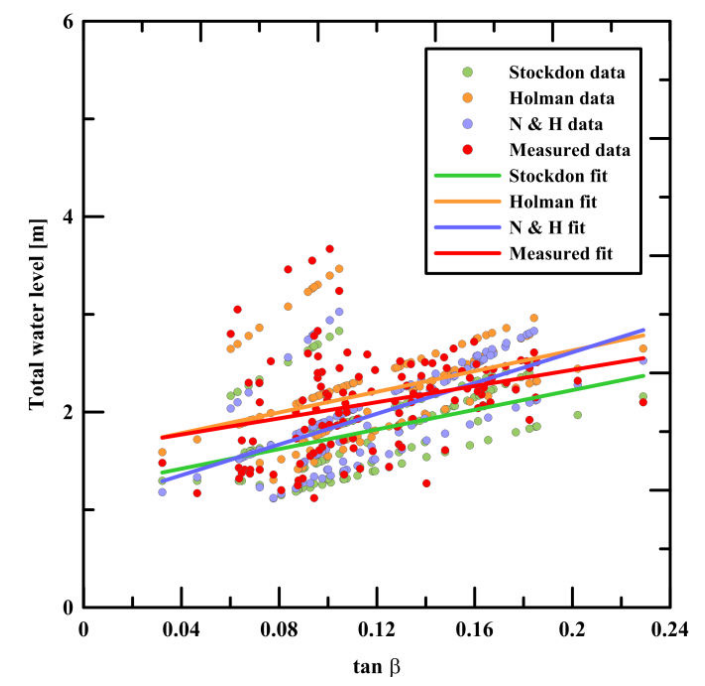

Figure 2. Assessment of ability of three empirical models to predict the total water level via comparison with measurements of maximum flood extent for variety of storm conditions and beach slopes

Data analysis showed that Stockdon model underestimated the wave run-up for the entire range of slopes (Figure 2). The N\& H model underpredicted considerably the TWL for mild slopes $(\tan \beta<0.15)$, while for larger slopes the opposite was valid. Holman model best coped with reproduction of observed TWL for mild slopes, but also tended to increasingly overestimate it as the beach slope grows. Obviously, the model results are problematic for reflective conditions but, on the other hand, there was a very small difference between estimates obtained with Holman and $\mathrm{N} \& \mathrm{H}$ models for those 
profiles. Based on this analysis, Holman model was preferred for application on 105 beach profiles with beach face slopes ranging between 0.01 and 0.26 .

Holman model predicts the run-up magnitude $R u_{2 \%}$ as [31]:

$$
R u_{2 \%}=H_{s}(0.83 \xi+0.2)
$$

where $H_{s}$ is significant wave height in deep water and $\xi$ is Iribarren number.

For artificial and rocky slopes, EurOtop formulation was employed [33]:

$$
R u_{2 \%} / H_{s}=1.65 \gamma_{b} \gamma_{f} \gamma_{\beta} \xi
$$

where $\gamma_{b}$ is berm influence factor, $\gamma_{f}$ - surface roughness factor and $\gamma_{\beta}$-influence factor of wave direction. EurOtop model was applied on 54 rocky and artificial profiles with slopes ranging between 0.04 and 0.56 .

The TWLs for all storm events that satisfied the POT criteria were calculated for each coastal sector. Resulting values were subjected to Extreme Value Analysis to establish the best fitting distribution to be Generalized Extreme Value (GEV) distribution (Figure 3).

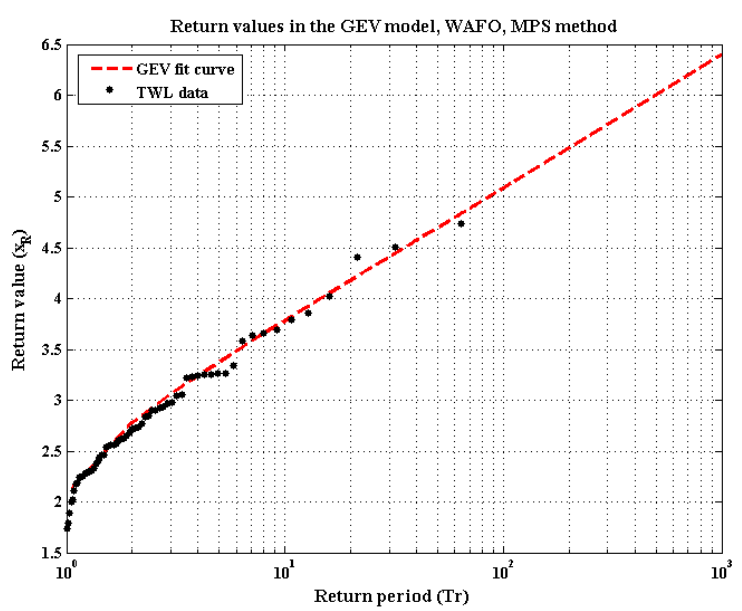

Figure 3. Example of TWL fit to GEV distribution for different return periods $\left(T_{r}\right)$; coastal sector 8 , profile 19

Hazard intensities relevant to return periods $\left(T_{r}\right)$ of 20, 50 and 100 years were further analyzed since they were considered benchmark values by most of the regional stakeholders [34]. Therefore, hazard indicator $\left(i_{h}\right)$ was calculated for above mentioned return periods and for both average and worst scenarios along Varna regional coast. Herein, map representation and hotspot identification were done based on the worst scenario with $T_{r}=100$ years.

\subsection{Hazard extent}

The hazard extents were determined using two approaches depending on the slope of the hinterland areas. In case of continuously rising slopes bathtub approach was applied. "Bathtubbing" (or equilibrium flood mapping) is a simplified method that is often utilized to re-draw coastal flood zones. It is essentially horizontal spreading of flood elevation data to areas of lower elevation [35]. For low-laying hinterland with dune presence, flood extent was calculated following [36]. If water level does not reach dune crest elevation, flood extent is the horizontal projection of the TWL, equal to $T W L / \tan \beta$. When water level exceeds the dune crest elevation, the extent is a sum of the horizontal distance from still water level to the dune crest, and the dune overwash extent, calculated by [37]:

$$
h(x)=h_{c} \exp \left(-a \frac{x}{u_{c}}\right)
$$

where $h(x)$ is flow depth on the back barrier slope as a function of distance $x, h_{c}$ - flood depth over the beach crest, $u_{c}$ - flow velocity at the dune crest, and $a$ is proportionality constant for infiltration.

\subsection{Exposure indicators}

Five types of exposure indicators are used to measure the relative exposure of different receptors to coastal flooding, namely: Land Use; Population; Transport systems; Utilities; Business settings [14]. Each of the five resultant indicators are ranked from 1 to 5: non-existent or very low (1), low (2), moderate (3), high (4) and very high (5) reflecting the degree of each receptor's exposure to flooding hazard.

The Land Use exposure indicator $\left(i_{\text {exp-LU }}\right)$ reflects two components for each coastal sector: the exposed surface and an associated importance value for each selected land use. Calculation of $i_{\text {exp-LU }}$ within the inundated area of each coastal sector is done by the formula:

$$
i_{\text {exp-LU }}=\sum_{j=1}^{n} S_{j} * V_{j},
$$

where $n$ is number of land use classes; $S$ is surface in $m^{2}$ of each land use class; $V$ is importance (weight) value assigned to each land use class (from 1 to 10). The final output is summation of all the areas per inundated zone in a coastal sector. For the present study the available land use classes were identified on the basis of Bulgarian Law on spatial planning [38].

The Population exposure indicator $\left(i_{\text {exp-POP }}\right)$ measures the relative exposure of different communities along the coast. As such, the indicator is similar to Social Vulnerability Index [39], which assesses the relative vulnerability of different areas to long-term health and financial recovery from an event, i.e. it considers the socio-economic characteristics of the areas exposed to certain hazards. In the present study the Social Flood Vulnerability Indicator (SFVI) [40] was adopted in combination with results from the project "Regional profiles - indicators of development" [41]. This approach was preferred because it was established that exact or closely similar to SFVI indicator of social vulnerability is not yet created for Bulgaria. The SFVI for Varna regional coast was adopted following [15], thus creating a simple SVI. It consists of seven variables falling into five categories: Financial deprivation (Unemployment, Noncar ownership, Non-home ownership), Health (Long-term sick), Household structure (Single parent), Age (Elderly $75+)$ and Education (Primary education). Data from 2011 Census were acquired for each variable on the 
lowest available level of disaggregation - municipality. Data on variables were transformed into percentages of the total population of each municipality, analyzed that they are not normally distributed, hence, subjected to additional normalization [40], and finally standardized as $\mathrm{Z}$ scores. Thus processed variables were put into a general equation to calculate the SVI for each municipality [15]:

$$
S V I=\sum_{j=0}^{n}\left(W_{j} * C_{j}\right),
$$

where $W_{j}$ is weight of each variable, $n$ - number of variables and $C_{j}$ - average of the variables.

Information about the following three indicators was collected by means of desktop research, field surveys and stakeholders interaction in order to map and to value each element of the systems.

\begin{tabular}{|c|c|c|}
\hline Value & Rank & Description \\
\hline 1 & $\begin{array}{c}\text { Non-existent } \\
\text { or very low }\end{array}$ & $\begin{array}{c}\text { No significant transport } \\
\text { network }\end{array}$ \\
\hline 2 & Low & $\begin{array}{c}\text { Mainly local and small } \\
\text { transport network }\end{array}$ \\
\hline 3 & Moderate & $\begin{array}{c}\text { Presence of transport } \\
\text { network with local/regional } \\
\text { importance }\end{array}$ \\
\hline 4 & High & $\begin{array}{c}\text { High density and multiple } \\
\text { networks (train, road, airport) } \\
\text { of local importance or } \\
\text { regional importance }\end{array}$ \\
\hline 5 & Very high & $\begin{array}{c}\text { High density and multiple } \\
\text { networks (train, road, airport) } \\
\text { of National or International } \\
\text { importance }\end{array}$ \\
\hline
\end{tabular}

Table 1. Ranking values for $i_{\text {exp-TS }}$

To construct the indicator for Transport systems $\left(i_{\text {exp- }}\right.$ $T S$ ) for each coastal sector a 5-step approach proposed in [15] was applied. Data on terrestrial transport networks (roads and railroads) location and relative importance (capacity and use) of their assets (links and nodes) was gathered. To assess the exposure of transport systems within the inundated area of each coastal sector road classification of Bulgaria [42] was taken into account and following the rules presented in Table 1 the exposure indicator $i_{\text {exp-TS }}$ was derived.

\begin{tabular}{|c|c|c|}
\hline Value & Rank & Description \\
\hline 1 & $\begin{array}{c}\text { Non-existent } \\
\text { or very low }\end{array}$ & $\begin{array}{c}\text { No significant utilities } \\
\text { networks/assets }\end{array}$ \\
\hline 2 & Low & $\begin{array}{c}\text { Mainly local and small } \\
\text { utilities networks/assets }\end{array}$ \\
\hline 3 & Moderate & $\begin{array}{c}\text { Presence of utilities } \\
\text { networks/assets with } \\
\text { local/regional importance }\end{array}$ \\
\hline 4 & High & $\begin{array}{c}\text { High dense and multiple } \\
\text { utilities networks/assets of } \\
\text { local importance or regional } \\
\text { importance }\end{array}$ \\
\hline 5 & Very high & $\begin{array}{c}\text { high dense and multiple } \\
\text { utilities networks/assets of } \\
\text { national or international } \\
\text { importance }\end{array}$ \\
\hline
\end{tabular}

Table 2. Ranking values for $i_{\text {exp-UT }}$
The indicator for Utilities $\left(i_{\text {exp-UT }}\right)$ for each coastal sector was obtained according to methodology proposed in [15]. Information on Utilities providing essential services, e.g. water, electricity, telecom networks and emergency centers, was collected. The assessment was done following the rules presented in Table 2, which led to derivation of $i_{\text {exp-UT }}$.

\begin{tabular}{|c|c|c|}
\hline Value & Rank & Description \\
\hline 1 & $\begin{array}{c}\text { Non-existent } \\
\text { or very low }\end{array}$ & $\begin{array}{c}\text { No significant economic } \\
\text { activities }\end{array}$ \\
\hline 2 & Low & $\begin{array}{c}\text { Mainly local small economic } \\
\text { activities }\end{array}$ \\
\hline 3 & Moderate & $\begin{array}{c}\text { Local or regional economic } \\
\text { activities }\end{array}$ \\
\hline 4 & High & Regional importance \\
\hline 5 & Very high & $\begin{array}{c}\text { National or international } \\
\text { importance }\end{array}$ \\
\hline
\end{tabular}

Table 3. Ranking values for $i_{\text {exp-BS }}$

Exposure indicator for Business settings $\left(i_{\text {exp-BS }}\right)$ was derived for each coastal sector following a 6-step approach proposed in [15]. Information on different business settings, including location of assets and their relative importance (input, output and number of businesses) was collected. Taking into account the gathered materials and following the rules of Table 3 the exposure indicator $i_{\text {exp-BS }}$ was obtained.

Finally, the overall exposure indicator $\left(i_{\text {exp }}\right)$ was computed as a geometric mean of all used and tailored indicators' values [14]:

$$
i_{\text {exp }}=\left[\left(i_{\text {exp-LU }} * i_{\text {exp-POP }} * i_{\text {exp }-T S} * i_{\text {exp }-U T} * i_{\text {exp-BS }}\right)\right]^{1 / 5}
$$

and resulting values were ranked from 1 to 5: nonexistent or very low (1), low (2), medium (3), high (4) and very high (5) reflecting the degree of receptors' exposure to flooding hazard.

\subsection{Coastal index}

The Coastal Index (CI) combines hazard intensities and related exposure vulnerability of selected receptors, thus, permitting evaluation of potential flood risk, which coastal sectors are subjected to. It was calculated using the formula [14]:

$$
C I=\left[\left(i_{h} * i_{\text {exp }}\right)\right]^{1 / 2}
$$

with $i_{h}$ standing for hazard indicator and $i_{\text {exp }}$ - overall exposure indicator. The resulting values were ranked from 1 to 5 .

\section{Results}

\subsection{Flooding hazard evaluation}

The coastal flooding hazard indicator $\left(i_{h}\right)$ was calculated using the TWL for each sector. However, due to the wide variety of existing morphological settings, this hazard parameter cannot be considered sufficient to obtain comparable results on its own. Hence, the estimation included the areas exposed to inundation 
regardless of land use classes. They were categorized in ten sets and each set was assigned a weight value, ranging from 0.05 to 1 . Then, a parameter Weighted TWL, merging hazard intensities and thus categorized hazard extents, was formulated. Accordingly, larger weights were assigned to those values of TWL that inundated broader hinterland areas.
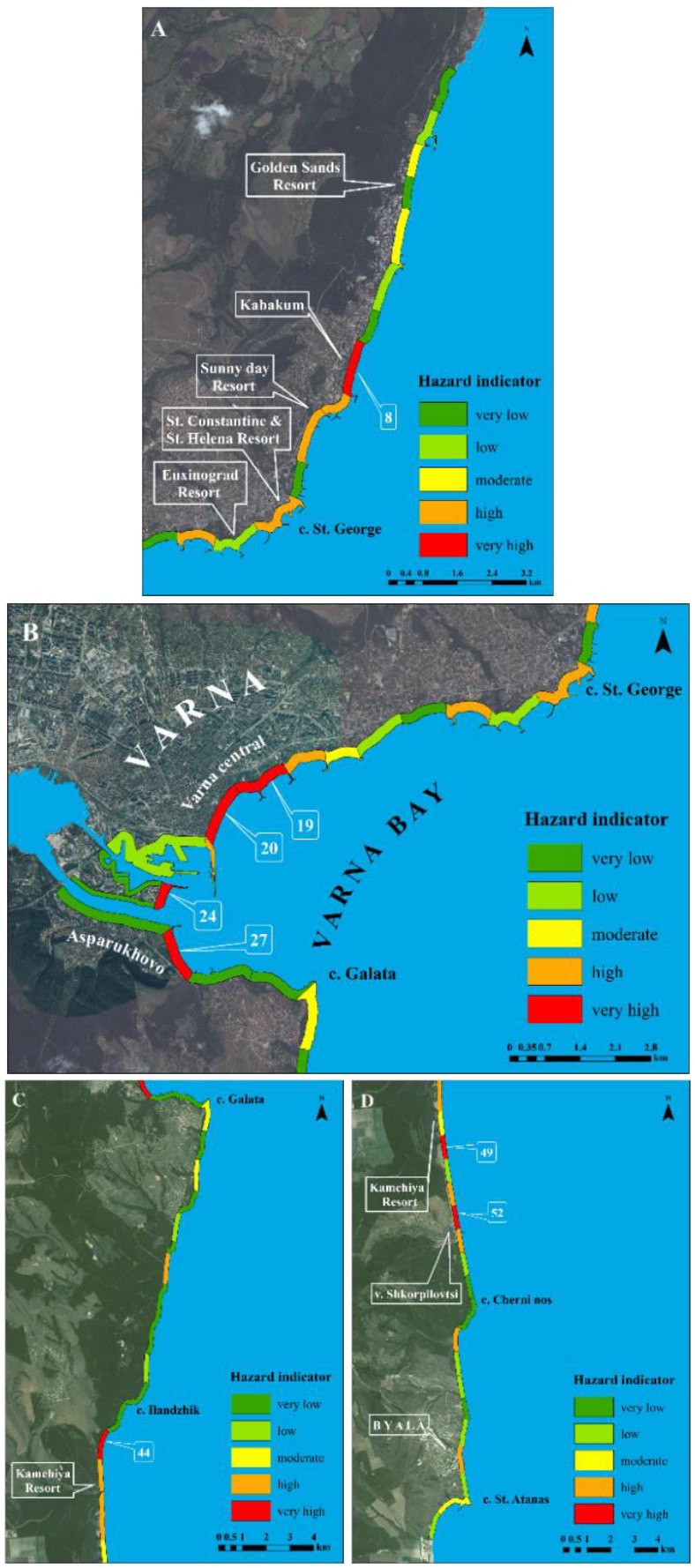

Figure 4. Coastal flooding hazard indicator $\left(i_{h}\right)$ along Varna regional coast; worst scenario, $T_{r}=100$ years

Subsequently, those values were ranked using the method of maximum breaks [43] in attempt to consider individual data values and group those that are similar. To this end, data sample was ordered from low to high, the differences between adjacent values were computed, and the largest of these differences served as class breaks. The ranking intervals are listed in Table 4.

\begin{tabular}{|c|c|c|}
\hline \multicolumn{2}{|c|}{ Ranking intervals } & Rank values \\
\hline 0 & 0.75 & 1 \\
\hline 0.75 & 1.2 & 2 \\
\hline 1.2 & 1.6 & 3 \\
\hline 1.6 & 2.2 & 4 \\
\hline 2.2 & $<$ & 5 \\
\hline
\end{tabular}

Table 4. Coastal flooding hazard indicator ranking

Colour mapping of flooding hazard indicator is shown in Figure 4. Highest and lowest values of $i_{h}$ were estimated as 3.68 and 0.14 , respectively. Results show that out of all 65 sectors $14(9,10,12,14,18,21,36,45$ $47,51,53,57,62)$ are with 'high' susceptibility to flooding hazard, while 8 sectors $(8,19,20,24,27,44,49$, 52) are ranked as 'very high'. They form three spatial clusters of vulnerable to flooding coastal stretches located within international seaside resorts (Kabakum beach, Sunny Day, St. Constantine \& St. Helena and Euxinograd), Varna Bay and tourist complexes in the southern part of the study site within KamchiyaShkorpilovtsi beach.

\subsection{Validation of flooding hazard}

Furthermore, results of coastal flooding hazard were validated against data of maximum run-up position measured during the intense storm of February 2012. Field surveys were performed at two sandy beaches within the study site domain: Varna central (sector 20), and Asparukhovo (sector 27). Additional dataset consisted of measurements of storm surge level and deep water significant wave height that allowed having insight of the forcing conditions.
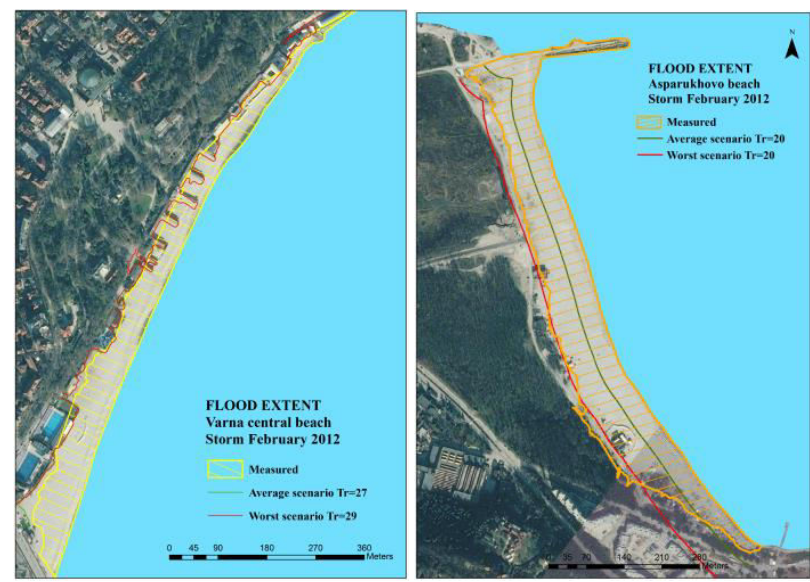

Figure 5. Validation of CRAF flood extents against measurements of February 2012 storm at two study site beaches: Varna central (sector 20) and Asparukhovo (sector 27)

Validation approach represents a comparison of measured flood extent and the reconstructed one corresponding to the TWL obtained in compliance with herein presented methodology. Besides, taking into account EVA results, return periods were assigned to the flooding hazard (for average and worst scenarios). Thus, comparison between real and estimated inundation was possible, testing the ability of CRAF to predict hazard 
intensities and correctly estimate the hazard indicator. Since the hazard intensity of 2012 storm comes towards CRAF $T_{r}=20$ event, presented results could be considered as validation of hazard indicator for that specific return period (Figure 5).

As it can be seen, in case of continuously rising slopes (Varna central beach), average and worst scenarios give quite similar extents that shows an excellent agreement with measurements. On the other hand, for low-laying hinterland (Asparukhovo beach), measurements show almost perfect concurrence with the worst scenario overwash extent, while for the average scenario it is halfway narrower than the measured one, which is evidently due to underestimation. On that account, indicators relevant for the worst scenario are illustrated in this paper.

\subsection{Exposure evaluation}

To calculate the Land Use exposure indicator $i_{\text {exp- } L U}$ the available land use classes [38] were merged to form more common classes in order to facilitate the valuation process. The assignment of importance value (1 to 10) to each class was done according to information gathered during stakeholders' interviews. The generalized land use classes and assigned importance values are presented in Table 5 .

\begin{tabular}{|c|c|c|c|}
\hline $\begin{array}{c}\text { ID } \\
\text { code }\end{array}$ & Land use classes & $\begin{array}{c}\text { Weight } \\
\text { value }\end{array}$ & $\%$ \\
\hline 1 & Discontinuous Urban fabric & 10 & 0.23 \\
\hline 2 & Mixed functionality urban fabric & 10 & - \\
\hline 3 & Ports & 9 & 3.99 \\
\hline 4 & Tourist resorts & 9 & 6.81 \\
\hline 5 & Industry & 8 & 1.17 \\
\hline 6 & Harbours & 7 & 3.25 \\
\hline 7 & Technical networks & 7 & 1.97 \\
\hline 8 & Green urban areas & 6 & 5.07 \\
\hline 9 & Special (Military, Naval, etc.) & 5 & 3.13 \\
\hline 10 & Sport \& Leisure facilities & 4 & 0.03 \\
\hline 11 & Agriculture & 4 & 0.68 \\
\hline 12 & Nature conservation & 4 & 3.37 \\
\hline 13 & Coastal protection & 4 & 6.32 \\
\hline 14 & Beaches, dunes & 3 & 58.14 \\
\hline 15 & Forest & 2 & 5.85 \\
\hline 16 & Barren & 1 & - \\
\hline 19 & Type of merged land use classes & asociat & $w$ \\
\hline
\end{tabular}

Table 5. Types of merged land use classes, associated weight values and relative proportion (\%) within inundated zones, worst scenario, $T_{r}=100$

The exposure indicator $i_{\text {exp-LU }}$ was calculated by equation (4) for each coastal sector within the inundated zones and ranked from 1 to 5 by data classification method - maximum breaks (Slocum, 1999). Table 5 also presents the relative proportion of land use classes for worst scenario, $T_{r}=100$.

As stated previously the exposure indicator for population $i_{\text {exp-POP }}$ was formed as a combination of the tailored SVI and results from [41]. Firstly, the SVI was estimated for the five coastal municipalities. Then, its values were reclassified in a scale from 1 to 5 . The results showed that the most vulnerable are the municipalities of Avren and Byala having ranks of 5 and 3, respectively. The low number of initial data suggests that they are not normally distributed and despite the transformation methods applied the results lacked representativeness since calculations were not performed for all 265 municipalities in Bulgaria. Supplementary information about socio-economic development of the entire Varna district in comparison to other districts in Bulgaria is presented in [41]. That research provides a snapshot of the socio-economic conditions in Bulgarian districts as of mid-2015, as well as their development since 2000. All 28 districts are clustered into 8 types and classified from 'very good' to 'very poor' socio-economic condition. According to this report, Varna district falls into the class of 'good' socio-economic conditions. This additional information allowed for a new reclassification of the SVI values in a scale from 1 to 3: 'very low', 'low' and 'medium' with ranking intervals determined by the method of equal intervals. Based on the new ranking Varna region coastal municipalities were assigned the following ranks representing the social vulnerability of the population: Aksakovo - 1, Varna - 1, Avren - 3, Dolni Chiflik - 1 and Byala - 2. Unfortunately, this approach does not allow assignment of a specific value for each coastal sector; therefore, a single value for all sectors within a given municipality was used. The proposed ranking suggests difficulty in claiming that the available data are representative for the exposed population along the coastline, particularly for sparsely populated coastal areas in municipalities of Aksakovo and Avren.

For qualitative assessment of Transport systems and derivation of $i_{\text {exp-TS }}$ road classification of Bulgaria [42] was taken into account and different road/railroad levels were ranked according to the rules in Table 1. Ranking values vary between 1 (local roads) and 5 (national high ways and railroads).

To assess Utilities the necessary information on location of assets for telecommunication and power supply within coastal hinterland (if any) were gathered during several field surveys and their presence (exposure to hazard) were taken into account during ranking. The same approach was used with respect to utilities in port and industry zones. Based on expert judgment of company managing the water networks (supply and sewage systems) in Varna district none of major assets are vulnerable to coastal flooding, since the water supply and sewage pipes are deeply underground and assets like water sources or pumping stations are located far from the coastline. Nevertheless, the presence of drainage pipes for ravine waters within the beaches was considered. As for emergency no large hospitals or medical complexes are located in the close vicinity to coastline, but field surveys localized the presence of 
small medical centers situated within beach domains and that also was taken into account during the ranking.

Based on [15] two business settings were identified within study site domain: 1) Beach frontage urban area (in the city of Varna) and seaside resort and 2) Port and related commercial and industrial zones. Within the first category fall the international resorts Euxinograd, St. Constantine \& St. Helena, Sunny day Co., Holiday Club Riviera and Golden sands located to the north of Varna city, as well as complexes Kamchiya and Long Beach (Shkorpilovtsi) situated to the south of cape Galata. Within the second category fall the industrial zone and the port complex situated deep into Varna Bay.

Due to the wide variety of existing coastal settings, location of different business assets and the fact that the inundation extents with few exceptions are predominantly within beach areas, the assignment of values to $i_{\text {exp-BS }}$ within each coastal sector was done according to authors' best judgment based on the information on different businesses presence gathered during several field surveys, desktop research and the rules in Table 3.

Finally, the ranks of all five exposure indicator were combined via equation (6) to form the overall exposure indicator $i_{\text {exp }}$. In order to classify the resulting data values the equal ranking intervals were used (Table 6).

\begin{tabular}{|c|c|c|}
\hline \multicolumn{2}{|c|}{ Ranking intervals } & Ranks \\
\hline 1 & 1.4 & 1 \\
\hline 1.4 & 1.8 & 2 \\
\hline 1.8 & 2.2 & 3 \\
\hline 2.2 & 2.6 & 4 \\
\hline 2.6 & $<$ & 5 \\
\hline
\end{tabular}

Table 6. Overall exposure indicator ranking intervals

Table 7 presents ranking results for overall exposure indicator $i_{\text {exp }}$, worst scenario, $T_{r}=100$ years. Highest and lowest values of $i_{\text {exp }}$ were estimated as 2.61 and 1, respectively.

\begin{tabular}{|c|c|c|}
\hline Ranks & $\begin{array}{c}\text { Ranks } \\
\text { description }\end{array}$ & Sectors \\
\hline 1 & $\begin{array}{c}\text { Non-existent or } \\
\text { very low }\end{array}$ & $\begin{array}{c}1,13-15,28-43,46-51, \\
55,56,58-61,63,65\end{array}$ \\
\hline 2 & Low & $\begin{array}{c}5-7,16,17,26,27,52- \\
54,57,61\end{array}$ \\
\hline 3 & Moderate & $\begin{array}{c}3,4,8-12,18-20, \\
44,62\end{array}$ \\
\hline 4 & High & $2,21-25,45,64$ \\
\hline 5 & Very high & - \\
\hline
\end{tabular}

Table 7. Ranking of the overall exposure indicator $i_{\text {exp }}$

Obviously, ranking does not exceed the value of 4 and even so only 8 sectors are ranked as 'high'. They are concentrated mostly within the inner curve of Varna Bay comprising port and industry facilities with regional, national and international significance.

\subsection{Coastal Index evaluation}

Coastal index values obtained by equation (7) were ranked following the method of equal intervals. The ranking intervals and assigned ranks are presented in Table 8 .

\begin{tabular}{|c|c|c|}
\hline \multicolumn{2}{|c|}{ Ranking intervals } & Ranks \\
\hline 1 & 1.5 & 1 \\
\hline 1.5 & 2.0 & 2 \\
\hline 2.0 & 2.5 & 3 \\
\hline 2.5 & 3.0 & 4 \\
\hline 3.0 & $<$ & 5 \\
\hline
\end{tabular}

Table 8. Coastal Index ranks and ranking intervals

Colour mapping of the Coastal Indices along Varna regional coast is presented in Figure 6.

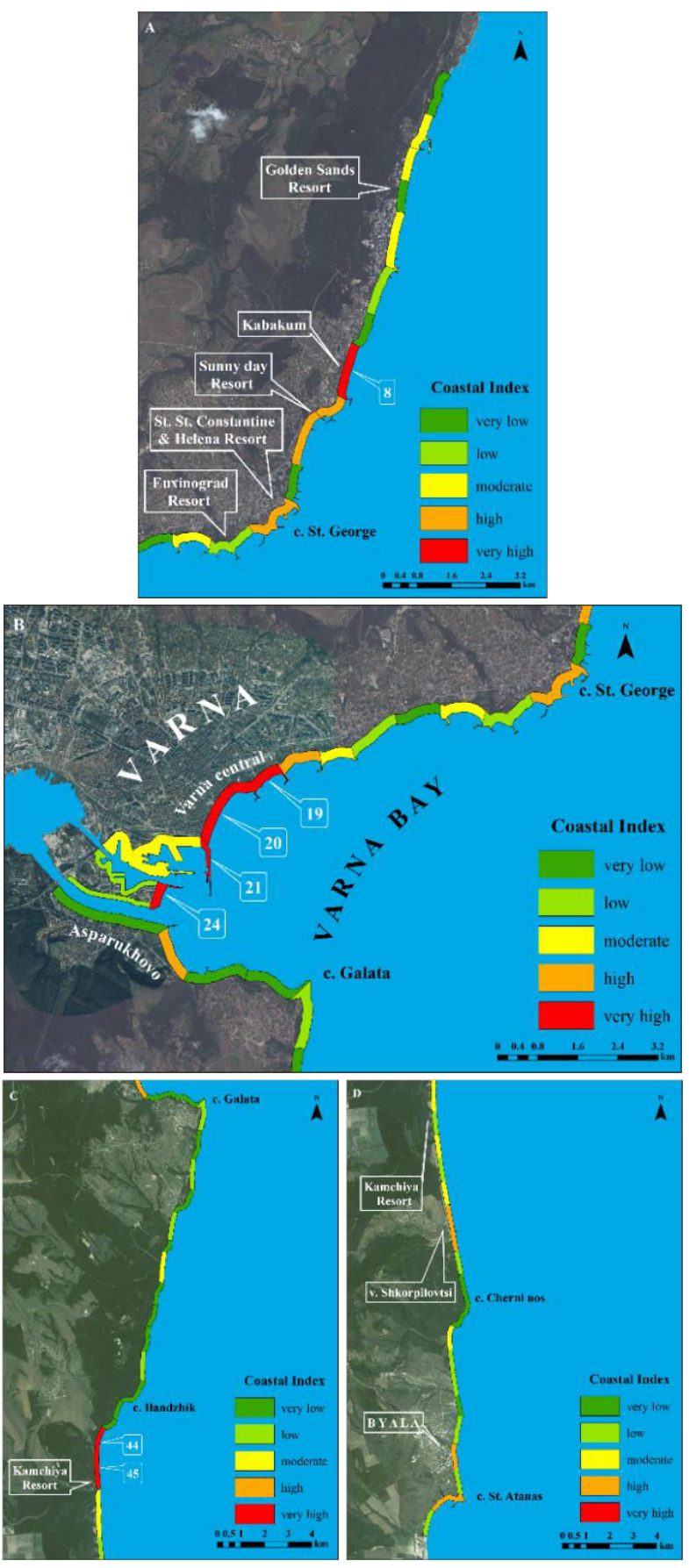

Figure 6. Coastal indices along Varna regional coast for worst scenario, $T_{r}=100$ years 
Highest and lowest values of CI were estimated as 3.44 and 1 , respectively. Results indicate 14 sectors with 'high' and 'very high' ranks $(8-10,18-21,24,44,45,52$, 53, 62 and 64), which are considered hotspot candidates. As in case of flooding hazard indicator, they are in the span of the seaside resorts to the north of Varna city (8$10), 5$ are presented by beaches, port and industrial zone within Varna Bay $(18-21,24)$, and, finally, 6 sectors (44, $45,52,53,62,64)$ are within smaller seaside resorts such as Kamchiya and Shkorpilovtsi.

\section{Discussion}

As mentioned above out of all 65 sectors 14 have 'high' susceptibility to flooding hazard, while 8 sectors are ranked as 'very high'. Reasons could be sought in the specificity of geomorphological settings defining the coastal response to given hazard intensities. With this respect, three groups of receptors can be determined within identified red sectors: 1) natural beaches, 2) man modified beaches and 3) artificial coasts. Natural beaches are geographically exposed to high-impact low-frequency storms hitting from the eastern half, while receptors in the latter two groups are somewhat protected from NE storms (except for Asparukhovo beach, sector 27).

Into the first group fall sectors 44,49 and 52. They are situated at open dissipative coast (KamchiyaShkorpilovtsi beach) with beach face slopes in the range of $0.08 \div 0.12$. The hinterland there is presented by lowlaying lands protected by dunes. Estimated TWLs for these sectors varies between 3.4 and $3.9 \mathrm{~m}$. These levels are as half as high the maximum TWL modelled within the regional coastal area $(6.7 \mathrm{~m})$. For that reason, inundated zones were within the beach limits but sufficient to represent a major threat to coastal environment.

The second group includes sectors 8, 19, 20 and 27. They are situated in the northern part of the study site, which is under anthropogenic pressure due to presence of coastal protection structures causing sediment supply shortage. Sectors 8 (Kabakum beach) and 20 (Varna central beach) are presented by relatively long sandy beaches with beach face slopes 0.3 and 0.17 , respectively. Moreover, they are of varying widths as being narrow in their northern part and wider to the south. Estimated TWLs varied between 4.3 and $5.7 \mathrm{~m}$, which are among the highest. Another vulnerable sector within the group is 19. The coast of the entire sector is protected by revetment, limited by two jetties with two small narrow sheltered beaches. Herein the estimated TWL was $5.14 \mathrm{~m}$ relevant to the revetment slope of 0.42 . The last sector 27 in this group is occupied by the long, wide and mild sloped (0.12) Asparukhovo beach backed by low-laying hinterland. Flooding potential was modelled with TWL $3.16 \mathrm{~m}$. Combination of the natural exposition of these sectors to forcing factors (surge and wave action) and the existing beach slopes led to the estimated hazard intensities, which caused inundation of entire beach bodies and even beyond impacting the hinterland and promenades.
The third group is presented by sector 24. At present, it is an entirely armoured forehead (slope 0.2) of artificially formed island - a remnant of the low-laying Varna sandy spit - situated between the two navigable canals. It comprises buildings, technical networks and facilities for industrial purposes. Herein, the estimated overwash extent exceeded $200 \mathrm{~m}$ being the main reason its hazard vulnerability to be qualified as 'very high'.

As for overall exposure indicator, results suggest that it is mainly controlled by presence of different business settings and affected land use in potentially vulnerable areas. The land use with highest exposure is beaches, as $58.14 \%$ of them are within inundated areas and are therefore at risk (Table 5). Providing that seaside resorts depend heavily upon their coastal locations and the beaches close to them, it is these assets that underpin tourism revenue within the municipal and regional economies. This means that tourist business is indirectly affected by flooding hazard but quantification of the degree and possible ripple effects is possible within a more detailed vulnerability modelling. Other land use classes with significant socio-economic value, e.g. urban fabric and industry, appear to be less or not exposed to flooding hazard. The absence of coastal sectors with 'very high' rank can also be attributed to low levels of exposure of population and assets related to transport and utilities.

A possible drawback in population vulnerability assessment could be ascribed to municipal scale of indicator estimation, since it does not reflect the vulnerability of inhabitants living in the vicinity of exposed areas. But given the very low density of population, if any, close to or within the affected zones this drawback has hardly biased the representativeness of the overall outcome.

Regarding the transport and utilities their exposure was ranked as 'low' or 'very low' since no major assets and/or networks were found to be under threat. Flooding of important road linkages are not likely to occur; therefore, the disruptive impact spreading along the coast and/or inland would be minor.

When combining results for hazard and exposure indicators, it is logical to expect that sectors represented by beaches, comprising tourist activity, and man modified coasts, occupied by port and industry, would be among those to obtain the highest CI ranks. At first glance, it might be considered that $\mathrm{CI}$ is hazard driven, since more than a few sectors are ranked as 'high' and 'very high' for both CI and $i_{h}$. However, sectors highly susceptible to flooding hazard have also 'moderate' to 'high' exposure vulnerability. This is particularly valid for subjected to multiple pressures Varna Bay. Therefore, it is considered the most vulnerable to flooding area within the study site.

\section{Conclusions}

Presented methodology, designed for estimation of potential risk of flooding within predefined coastal sectors, demonstrated very good ability to predict hazard intensity, extent and related receptors' exposure 
vulnerability. Alongshore variations of weighted TWL parameter merging information on hazard intensities and extents - were considered for assessment of flooding hazard indicator. Social vulnerability as well as potentially affected land use, transport systems, utilities and business settings were used to construct exposure indicators. Final outcome combines hazard and exposure indicators into a single Costal Index, thereby allowing identification of hotspots. Validation proved that in case of continuously rising slopes average and worst scenarios, obtained via bathtubbing, give quite similar extents, which agree excellently with measurements, while in case of low-laying hinterland overwash extent within the worst scenario provides better results in comparison to average one.

It was found that identified hotspot candidates form three spatial clusters of vulnerable to flooding coastal stretches located in Varna Bay, as well as within international seaside resorts and smaller tourist complexes to the north and south of Varna city, respectively. Thus, sectors represented by beaches, comprising tourist activity, and man modified coasts, occupied by port and industry, were among those to obtain the highest CI ranks. CI is almost equally influenced by hazard and exposure indicators. This is particularly valid for subjected to multiple pressures Varna Bay where the highest number of hotspots were identified. Therefore, it is considered the most vulnerable to flooding area within the study site. Having those findings in mind, it is required a further development of adequate hazard prediction and assessment tools in support to local stakeholders and decision makers, as well as a re-evaluation of coastal disaster risk reduction strategies and placing a new set of prevention, mitigation and preparedness measures.

\section{Acknowledgements}

The work described in this publication was supported by the European Community's $7^{\text {th }}$ Framework Programme in the frame of RISC-KIT project (GA no. 603458).

\section{References}

1. Bertin X., Bruneau N., Breilh J.F., Fortunato A.B. and M. Karpytchev (2012). Importance of wave age and resonance in storm surges: The case Xynthia, Bay of Biscay, Ocean Modelling, 42, 16-30.

2. Silvestro F., Gabellani S., Giannoni F., Parodi A., Rebora N., Rudari R., and F. Siccardi (2012). A hydrological analysis of the 4 November 2011 event in Genoa. Nat. Hazards Earth Syst. Sci., 12, 27432752.

3. Lamb H. H. (1991). Historic Storms of the North Sea, British Isles and Northwest Europe, Cambridge University Press, 204 p.

4. Trifonova E., Valchev N., Andreeva N. and P. Eftimova (2012). Critical storm thresholds for morphological changes in the western Black Sea coastal zone, Geomorphology, vol. 143-144, 81-94.
5. Arkhipkin V. S., Gippius F. N., Koltermann K. P., and G. V. Surkova (2014). Wind waves in the Black Sea: results of a hindcast study, Nat. Hazards Earth Syst. Sci., 14, 2883-2897.

6. Galabov V., Kortcheva A., Bogatchev A., and B. Tsenova (2015). Investigation of the hydrometeorological hazards along the Bulgarian coast of the Black Sea by reconstructions of historical storms. Journal of Environmental Protection and Ecology, 16(3), 1005-1015.

7. Valchev N., Trifonova E. and N. Andreeva (2012). Past and recent trends in the western Black Sea storminess, Nat. Hazards Earth Syst. Sci., vol. 12, 117, doi:10.5194/nhess-12-961-2012.

8. Akpınar A. and M.T. Kömürcü (2013). Assessment of wave energy resource of the Black Sea based on 15-year numerical hindcast data. Applied Energy, 101, 502-512.

9. Rusu L., Butunolu D. and E. Rusu (2014). Analysis of the Extreme Storm Events in the Black Sea Considering the Results of a Ten-year Wave Hindcast. Journal of Environmental Protection and Ecology, 15 (2), 445-454.

10. Quevauviller P., Barceló D., Beniston M., Djordjevic S., Harding R. J., Iglesias A., Ludwig R., Navarra A., Ortega A. N., Mark O., Roson R., Sempere D., Stoffel M., van Lanen H. A. J. and M. Werneret (2012). Integration of research advances in modelling and monitoring in support of WFD river basin management planning in the context of climate change. Science of the Total Environment, 440, 167177.

11. Collet I. and A. Engelbert (2013). Coastal regions: people living along the coastline, integration of NUTS 2010 and latest population grid, EUROSTAT.

12. The EU Floods Directive 2007/60, http://ec.europa.eu/environment/water/flood_risk;

13. Van Dongeren A., Ciavola P., Viavattene C., De Kleermaeker S., Martinez G., Ferreira O., Costa C. and R. McCall (2014). RISC-KIT: ResilienceIncreasing Strategies for Coasts - toolKIT. In: Green, A.N. and Cooper, J.A.G. (eds.), Proceedings 13th International Coastal Symposium (Durban, South Africa), Journal of Coastal Research, SI. 70, 366-371.

14. Viavattene C., Jimenez J.A., Owen D., Priest S.J., Parker D.J., Micou P. and S. Ly (2015b). Coastal Risk Assessment Framework: Guidance Document, EU FP7 603458 research project RISC-KIT Deliverable No: D.2.3, 155 p.

15. Viavattene C., Micou P., Owen D., Priest S.J. and D.J. Parker (2015a). Library of Coastal Vulnerability Indicators: Guidance Document, EU FP7 603458 research project RISC-KIT - Deliverable No: D.2.2, $136 \mathrm{p}$.

16. Gornitz V.M. (1990). Vulnerability of the East Coast. Journal of Coastal Research, SI. 9, pp. 201237.

17. McLaughlin S. and J.A.G. Cooper (2010). A multiscale coastal vulnerability index: A tool for coastal managers? Environmental Hazards, 9(3), 233-248. 
18. Balica S.F., Wright N.G. and F. van der Meulen (2012). A flood vulnerability index for coastal cities and its use in assessing climate change impacts, Natural Hazards, 64(1), 73-105.

19. Clark G., Moser S., Ratick S., Dow K., Meyer W., Emani S., Jin W., Kasperson J., Kasperson R. and H. Schwartz (1998). Assessing the vulnerability of coastal communities to extreme storms: The case of Revere, MA, USA. Mitigation and Adaptation Strategies for Global Change, 3(1), 59-82.

20. Benassai G., Chirico F. and S. Corsini (2009). Una metodologia sperimentale per la definizione del rischio da inondazione costiera. Studi costieri, 16, 51-72.

21. Fernández V., Gómez M. and B. Guigou (2013). Coastal vulnerability index to global change in Uruguay, Proceedings of 11th International Symposium for GIS and Computer Cartography for Coastal Zones Management, Victoria, British Columbia, Canada, 42-44.

22. Appeaning Addo, K. (2013). Assessing Coastal Vulnerability Index to Climate Change: the Case of Accra - Ghana, Proceedings $12^{\text {th }}$ International Coastal Symposium (Plymouth, England), Journal of Coastal Research, SI. 65, 1892-1897.

23. Valchev N., Andreeva N., Eftimova P. and E. Trifonova (2014). Prototype of early warning system for coastal storm hazard (Bulgarian Black Sea coast), Compt. Rend. Acad. Bulg. Sci., 67 (7), 971-978.

24. Villatoro M., Silva R., Méndez F.J., Zanuttigh B., Pan S., Trifonova E., Losada I.J., Izaguirre C., Simmonds D., Reeve D.E., Mendoza E., Martinelli L., Formentin S.M., Galiatsatou P., and P. Eftimova (2014). An approach to assess flooding and erosion risk for open beaches in a changing climate. Coastal Engineering, Vol. 87, 50-76.

25. Stanchev H., Young R. and M. Stancheva (2013). Integrating GIS and high resolution orthophoto images for the development of a geomorphic shoreline classification and risk assessment - a case study of cliff/bluff erosion along the Bulgarian coast. Journal of Coastal Conservation, 17(4), 719-728.

26. Garrity N.J., Battalio R., Hawkes P.J. and D. Roupe (2006). Evaluation of the event and response approaches to estimate the 100-year coastal flood for Pacific coast sheltered waters. Proceeding of the $30^{\text {th }}$ ICCE, ASCE, 1651-1663.

27. Valchev N., Davidan I., Belberov Z., Palazov A. and N. Valcheva (2012). Hindcasting and assessment of the western Black sea wind and wave climate, Journal of Environmental protection and ecology, 11(3), 1001-1012.

28. Feser F., Weisse R., and H. von Storch (2001). Multidecadal atmospheric modelling for Europe yields multi-purpose data, EOS, 82 (28), 305-310.

29. Trifonova E., N. Valchev N. Andreeva and P. Eftimova (2012). Critical storm thresholds for morphological changes in the western Black Sea coastal zone, Geomorphology, vol. 143-144, 81-94.

30. Stockdon H.F., Holman R.A., Howd P.A. and A.H. Sallenger Jr. (2006). Empirical parameterization of setup, swash, and run-up, Coastal Engineering, 53(7), 573-588.

31. Holman R. A. (1986) Extreme value statistics for wave run-up on a natural beach, Coastal Engineering, 9 (6), 527-544.

32. Nielsen P. and D.J. Hanslow (1991). Wave run-up distributions on natural beaches, Journal of Coastal Research, 7(4), 1139-1152.

33. Pullen T., Allsop N.W.H., Bruce T., Kortenhaus A., Schüttrumpf H. and J.W. van der Meer (2007). EurOtop. Wave overtopping of sea defenses and related structures: Assessment manual, 193 p., www.overtopping-manual.com.

34. Dimitrov D., Nyagolov I., Balabanova S., Lisev N., Koshinchanov G., Korcheva A., Marinski Y., Pashova L., Grozdev D., Vasilev V., Bozhilov and N. Tsvetkova (2013). Methods for assessment of flood hazard and flood risk, according to requirements of the EU Floods Directive 2007/60: Final Report, Black Sea Basin Directorate, Contract No D-30-62, 357 p. (In Bulgarian).

35. Orton P., Vinogradov S., Blumberg A. and N. Georgas (2014). Hydrodynamic mapping of future coastal flood hazards for New York City, Revised final project report, Stevens Institute of Technology, $36 \mathrm{p}$.

36. Donnelly C. (2008). Coastal Overwash: Processes and Modelling. Ph.D. Thesis, University of Lund, $53 \mathrm{p}$.

37. Plomaritis T.A., Costas S. and O. Ferreira (2015). Overwash hazards assessment using a simplified process based approach, Geo-temas, 15, 129-132.

38. Law on spatial planning (2015). Official Gazette, 65.

39. Flanagan B., Gregory E., Hallisey E., Heitgerd J. and B. Lewis (2011). A social vulnerability index for disaster management, Journal of homeland security and emergency management, 8 (1), Article 3.

40. Tapsell S.M., Penning-Rowsell E.C., Tunstall S.M. and T. Wilson (2002). Vulnerability to flooding: health and social dimensions. Phil. Trans. R. Soc. Lond., 360 (1796), 1511-1525.

41. Nikolova D., Tsvetkov A., Ganev P., Aleksiev Y. and Z. Slavova (2014). Regional profiles - indicators of development, Report on the project "Regional Profiles: Indicators of Development" financed by the America for Bulgaria Foundation”, 170 p.

42. Ordinance No 2 for planning and design of transport and communication systems in urbanized territories (2204). Official Gazette, 86.

43. Slocum T. A. (1999). Thematic cartography and Visualization. Upper Saddle River: Prentice Hall Inc. 